\title{
Erratum to: Studies of trypanosomiasis in the Luangwa valley, north-eastern Zambia

\author{
Dusit Laohasinnarong ${ }^{1,2}$, Yasuyuki Goto ${ }^{1,3}$, Masahito Asada' ${ }^{1}$ Ryo Nakao ${ }^{4}$, Kyoko Hayashida ${ }^{4}$, Kiichi Kajino ${ }^{4}$, \\ Shin-ichiro Kawazu', Chihiro Sugimoto ${ }^{4}$, Noboru Inoue ${ }^{1}$ and Boniface Namangala ${ }^{5 *}$
}

Unfortunately, the original version of this article [1] contained a mistake. The spelling of Yasuyuki Goto's name was incorrectly given as Yasuhuki Goto. The correct spelling is Yasuyuki Goto and is included correctly in the author list of this article.

In addition, some author affiliations were assigned incorrectly. Yasuyuki Goto additionally belongs to affiliation 3, which should be listed as 'Laboratory of Molecular Immunology' and not 'Department of Molecular Immunology'. Masahito Asada was incorrectly assigned to affiliation number 3, but belongs to affiliation 1. This has been corrected in the affiliation list of this article.

\section{Author details \\ 'O.I.E. Reference Laboratory on Surra, National Research Center for Protozoan Diseases, Obihiro University of Agriculture and Veterinary Medicine, Inada-cho, Obihiro 080-8555, Hokkaido, Japan. ${ }^{2}$ Clinical Sciences and Public Health Department, Faculty of Veterinary Science, Mahidol University, 999 Phuttamonthon 4 Road, Salaya, Phuttamonthon, Nakhon Pathom 73170, Thailand. ${ }^{3}$ Laboratory of Molecular Immunology, Graduate School of Agricultural and Life Sciences, The University of Tokyo, Bunkyo-ku 113-8657, Tokyo, Japan. ${ }^{4}$ Research Center for Zoonosis Control, Hokkaido University, Sapporo 060-0818, Hokkaido, Japan. ${ }^{5}$ Department of Paraclinical Studies, School of Veterinary Medicine, University of Zambia, Lusaka P.O. Box 32379, Zambia.}

Received: 19 October 2015 Accepted: 19 October 2015

Published online: 22 October 2015

\section{Reference}

1. Laohasinnarong D, Goto Y, Asada M, Nakao R, Hayashida K, Kajino K, et al. Studies of trypanosomiasis in the Luangwa valley, north-eastern Zambia. Parasit Vectors. 2015;8:497.

\footnotetext{
* Correspondence: b.namangala@unza.zm

${ }^{5}$ Department of Paraclinical Studies, School of Veterinary Medicine, University of Zambia, Lusaka P.O. Box 32379, Zambia
}

\section{Submit your next manuscript to BioMed Central} and take full advantage of:

- Convenient online submission

- Thorough peer review

- No space constraints or color figure charges

- Immediate publication on acceptance

- Inclusion in PubMed, CAS, Scopus and Google Scholar

- Research which is freely available for redistribution

\section{Biomed Central}

(c) 2015 Laohasinnarong et al. Open Access This article is distributed under the terms of the Creative Commons Attribution 4.0 International License (http://creativecommons.org/licenses/by/4.0/), which permits unrestricted use, distribution, and reproduction in any medium, provided you give appropriate credit to the original author(s) and the source, provide a link to the Creative Commons license, and indicate if changes were made. The Creative Commons Public Domain Dedication waiver (http://creativecommons.org/publicdomain/zero/1.0/) applies to the data made available in this article, unless otherwise stated. 